\title{
Fungsi Komunikasi Organisasi Internal Selama Pandemi Covid-19 : Studi Kasus di Organisasi Pendidikan
}

\author{
Lydia Fahmawati ${ }^{1}$, Cheerli ${ }^{2}$ dan Idham Imarshan ${ }^{3}$ \\ 1,2,3 Magister Ilmu Komunikasi, Universitas Paramadina \\ Jalan Gatot Subroto Kavling 97 Jakarta Selatan 12790 \\ ${ }^{1}$ Email: lydia.fahmawati@students.paramadina.ac.id \\ 2Email: cheerli@ students.paramadina.ac.id \\ ${ }^{3}$ Email: idham.imarshan@ students.paramadina.ac.id
}

* Corresponding Author. E-mail: lydia.fahmawati@students.paramadina.ac.id

\begin{tabular}{|l|l|l|}
\hline Receive: 13/05/2021 & Accepted: 23/08/2021 & Published: 01/10/2021
\end{tabular}

\begin{abstract}
Abstrak
Pemerintah menerapkan peraturan Pembatasan Sosial Berskala Besar (PSBB) atas adanya wabah Corona Virus Disease (COVID-19) di Indonesia. Hal ini tentunya mengubah aktivitas masyarakat yang harus melakukan seluruh kegiatan seperti belajar, bekerja dan beribadah dari rumah. Dalam artikel ini, fokus penelitian dilakukan pada bentuk fungsi-fungsi komunikasi organisasi yang dilaksanakan pada masa krisis Pandemi COVID-19. Bagaimana suatu organisasi di masa Pandemi COVID-19 ini melaksanakan fungsi komunikasi organisasi agar kegiatan-kegiatan dalam organisasi tetap berjalan dengan baik meskipun banyak perubahan yang terjadi baik dari segi peraturan yang harus diterapkan maupun teknologi yang harus digunakan. Penelitian ini menggunakan pendekatan kualitatif dengan metode studi kasus. Objek dalam penelitian ini adalah Kalbis Institute yang merupakan sebuah perguruan tinggi di Jakarta. Subjek penelitian yang merupakan informan adalah karyawan Kalbis Institute. Hasil penelitian ini berupa bentuk-bentuk fungsi komunikasi organisasi yang dilaksanakan di Kalbis Institute di tengah masa Pandemi COVID-19.
\end{abstract}

Kata Kunci: Fungsi Komunikasi Organisasi, Pandemi COVID-19, Komunikasi Organisasi Internal

\begin{abstract}
The government implements a Large-Scale Social Restriction (PSBB) regulation for the Corona Virus Disease (COVID-19) outbreak in Indonesia. The regulation, of course changes people's activities that must carry out all activities such as studying, working and praying from home. In this article, the focus of research is on the form of organizational communication functions carried out during the COVID-19 pandemic crisis. How did an organization during the COVID-19 pandemic carry out the organizational communication function so that activities within the organization continue to run well even though many changes have occurred, both in terms of regulations that must be implemented and technology that must be used. This research uses a qualitative approach with case study methods. The object of this research is the Kalbis Institute which is a institute at Jakarta. The research subjects who were informants were employees of the Kalbis Institute. The results of this study are forms of organizational communication functions carried out at the Kalbis Institute in the midst of the COVID-19 Pandemic.

Keyword: Function of Organizational Communications, COVID-19 Pandemic, Internal Organizational Communication
\end{abstract}

\section{Pendahuluan}

Corona Virus Disease atau yang biasa disebut dengan COVID-19 merupakan sebuah virus menular yang ditemukan pertama kali di Wuhan, China pada bulan Desember 2019 (Alodokter, 2020). Virus ini dapat menular melalui batuk, bersin, bahkan hembusan nafas orang yang terinfeksi yang jatuh ke permukaan. Pada bulan Januari 2020, virus ini mulai menular ke berbagai negara. Virus menular ini dianggap serius karena penularannya termasuk cepat, sebagian tanpa gejala dan dapat menyebabkan kematian jika dilihat dari kasus-kasus orang yang terinfeksi yang sudah ada. 
Oleh karena itu, pencegahan penularan virus ini dilakukan oleh dan di berbagai negara. Di Indonesia sendiri, upaya preventif penularan COVID-19 pertama kali dilakukan pada bulan Januari 2020 dengan melakukan pengawasan ketat jalur masuk ke Indonesia dan menutup sementara penerbangan ke China. Dicatat bahwa COVID-19 masuk ke Indonesia pada awal minggu pertama di bulan Maret 2020. Data tersebut didukung dengan respon yang juga langsung diberikan Pemerintah Indonesia pada bulan Maret 2020. Pemerintah Indonesia melalui Presiden Jokowi pada hari Minggu, tanggal 15 Maret 2020 di Istana Bogor, Jawa Barat menghimbau masyarakat untuk tidak panik dan melakukan segala aktivitas dari rumah, termasuk belajar, bekerja dan beribadah (Kompas.com, 2020).

Meskipun telah dihimbau oleh Pemerintah untuk tidak panik menghadapi COVID-19 yang telah masuk ke Indonesia, namun kepanikan tetap terjadi di masyarakat. Kepanikan masyarakat ditandai dengan kegiatan pembelian SEMBAKO (Sembilan Bahan Pokok) secara berlebihan. Hal ini tentunya didasari oleh ketakutan masyarakat bahwa di Indonesia akan diberlakukan sistem lockdown seperti di Wuhan, China yang mana akan mengakibatkan masyarakat kesulitan mendapatkan bahan makanan. Melihat situasi yang ada, Pemerintah menyampaikan kembali kepada masyarakat melalui Menteri Perdagangan untuk tidak panik dan akan memastikan kebutuhan bahan pokok tercukupi (Media Indonesia, 4/3/2020). Perkembangan kasus COVID-19 di Indonesia sangat cepat, dalam waktu 11 hari, jumlah kasus positif naik berkali-kali lipat. Hal ini yang membuat Pemerintah melakukan beberapa tindakan seperti, pembentukan Tim Gugus Tugas Penanganan COVID-19, pemberlakuan Pembatasan Sosial Berskala Besar (PSBB), pembuatan kebijakan belajar dari rumah untuk pelajar dan mahasiswa, serta menyerahkan status kedaruratan daerah kepada kepala daerah masing-masing. Sampai dengan saat ini, berdasarkan situs laman covid19.co.id ada sekitar kurang lebih sembilan puluhan dokumen peraturan, keputusan, surat edaran, dan lainnya yang dikeluarkan Pemerintah terkait dengan COVID-19 (Komite Penanganan COVID-19 dan Pemulihan Ekonomi Nasional, 2020).

Tidak sama seperti yang dilakukan beberapa negara yang memberlakukan sistem lockdown, di Indonesia penanganan pencegahan COVID-19 dilakukan dengan kebijakan Pembatasan Sosial Berskala Besar (PSBB). Pada hari Selasa, tanggal 31 Maret 2020 Pemerintah mengeluarkan Peraturan Pemerintah No. 21 Tahun 2020 tentang Pembatasan Sosial Berskala Besar dalam Rangka Percepatan Penanganan Corona Virus Disease 2019 (COVID-19). Tentunya hal ini dilakukan dengan pertimbanganpertimbangan yang akan berdampak dari kebijakan yang diterapkan, terutama dampak yang paling besar yaitu dari segi ekonomi. Mengikuti instruksi dari Pemerintah Pusat, di Jakarta diberlakukan PSBB yang mengharuskan masyarakat melakukan seluruh kegiatan dari rumah, kecuali delapan sektor usaha. Dengan adanya situasi dan kondisi Pandemi COVID-19 ini, kemudian ditambah dengan kebijakan dari Pemerintah tersebut, tentunya hal ini sangat berpengaruh terhadap seluruh bidang usaha baik kecil, menengah maupun besar.

Pengaruh COVID-19 terhadap bidang usaha atau perusahaan bukan hanya dari segi proses bisnis yang dijalankan, akan tetapi juga komunikasi yang terjalin di dalam perusahaan baik dengan pihak internal maupun eksternal perusahaan. Perusahaan dituntut harus menerapkan beberapa kebijakan yang telah diberlakukan oleh Pemerintah, jika tidak akan ada sanksi yang diberikan. Kebijakan-kebijakan tersebut adalah seperti memberlakukan sistem bekerja dari rumah (work from home) untuk karyawan, menerapkan protokol kesehatan di tempat kerja, membentuk tim gugus tugas pencegahan penularan COVID-19, dan lainnya. Dalam merespon situasi dan kondisi yang ada, perusahaan haruslah cepat mengambil keputusan dalam membuat dan menjalankan kebijakan tersebut. Perusahaan juga harus melakukan inovasi dalam menghadapi tantangan digitalisasi di era internet yang mana situasi dan kondisi saat ini semua dilakukan secara daring. Kemudian setelah seluruh kebijakan yang dibuat selesai, perusahaan haruslah mensosialisasikannya kepada seluruh stakeholders bisnisnya untuk tetap menjaga komunikasi berjalan dengan baik. Selain berdampak pada proses bisnis di semua bidang usaha, Pandemi COVID-19 ini juga telah mengubah pola komunikasi baik komunikasi antar pribadi maupun komunikasi organisasi. Perubahan tersebut dikarenakan bentuk komunikasi yang dahulu selalu dilakukan secara langsung atau luring, kini harus berjarak dan dilakukan secara daring.

Seperti yang telah digambarkan di atas, situasi dan kondisi Pandemi COVID-19 membawa dampak besar terhadap suatu perusahaan, yang mana perusahaan harus berjuang mempertahankan usahanya, berinovasi dengan tuntutan teknologi, bersinergi dengan peraturan dan kebijakan baru, dan beradaptasi dengan situasi dan kondisi di mana semua aktivitas dilakukan dari rumah. Upaya-upaya yang dilakukan perusahaan tersebut tentunya harus dikomunikasikan kepada karyawan agar terdapat kesamarataan penerimaan informasi sehingga karyawan dapat melakukan kegiatan-kegiatan sesuai dengan peraturan yang berlaku untuk bersama-sama mencapai tujuan organisasi. Komunikasi organisasi yang terjalin di internal perusahaan selama masa Pandemi COVID-19 inilah yang menjadi fokus dalam penelitian ini. Hal ini 
Jurnal Edumaspul, 5 (2), Year 2021- 416 (Lydia Fahmawati, Cheerli, Idham Imarshan)

menjadi menarik untuk diteliti dengan tujuan untuk mengetahui bagaimana perusahaan menjalankan fungsi komunikasi organisasi di masa Pandemi COVID-19. Penelitian terkait dengan komunikasi organisasi sudah banyak dilakukan, namun komunikasi organisasi yang dilakukan pada masa Pandemi COVID-19 pastinya belum banyak karena Pandemi COVID-19 masih berlangsung sampai dengan saat ini.

Fungsi komunikasi organisasi yang dimaksud adalah fungsi regulatif, informatif, integratif, dan persuasif. Penelitian yang pernah dilakukan mengenai komunikasi organisasi sebelumnya menyatakan bahwa fungsi komunikasi organisasi (regulatif, informatif, integratif, dan persuasif) menjadi bahan evaluasi, kontrol, motivasi, serta melakukan pembinaan karyawan secara berkala dalam bersikap dan berperilaku. Selain itu dari hasil penelitian tersebut juga disampaikan bahwa kesamarataan referensi dan penyamaan persepsi pada empat fungsi komunikasi organisasi dapat menumbuhkan bentuk partisipasi yang lebih besar dan lebih bertanggung jawab terhadap diri karyawan untuk mematuhi peraturan dan melakukan pekerjaan dengan baik (Zuali, 2017). Berdasarkan hal tersebut, dapat disimpulkan bahwa komunikasi organisasi banyak membawa manfaat dalam organisasi apabila dijalankan dengan baik. Selain itu, penelitian lain terkait dengan komunikasi organisasi internal (Mutiara dkk, 2017) menyatakan bahwa adanya hubungan vertikal antara atasan dengan bawahan atau sebaliknya dan hubungan horizontal antara sesama karyawan. Dari hasil penelitian tersebut disimpulkan bahwa hubungan baik yang terjalin baik pada hubungan vertikal dan horizontal akan mempengaruhi karyawan untuk saling bekerja sama sehingga meningkatkan kinerjanya.

Hasil dari penelitian dalam artikel ini lebih difokuskan kepada pelaksanaan fungsi komunikasi organisasi internal selama masa Pandemi COVID-19 yang tentunya untuk menunjang kinerja karyawan melakukan pekerjaannya dalam mencapai tujuan bersama organisasi. Penelitian ini dilakukan pada Kalbis Institute yang merupakan organisasi yang bergerak di bidang pendidikan. Hasil dari penelitian ini tentunya akan bermanfaat sebagai pengembangan model komunikasi organisasi di masa krisis. Untuk Kalbis Institute sendiri, penelitian ini dapat digunakan sebagai bahan evaluasi untuk perbaikan komunikasi organisasi internal.

\section{Kajian teori}

Secara sederhana, komunikasi merupakan sebuah proses penyampaian informasi dari suatu individu atau kelompok yang biasa disebut dengan komunikator kepada individu atau kelompok lain yang biasa disebut dengan komunikan. Jika dikaitkan dengan penelitian ini, definisi komunikasi yang dikemukakan oleh Frank Dance adalah yang paling cocok, yang mendefinisikan komunikasi sebagai sebuah sistem untuk menyampaikan informasi dan perintah (Littlejohn, 2019, h. 4). Dalam penelitian ini, hal utama yang akan dibahas yaitu komunikasi organisasi. Jika sebelumnya telah didefinisikan mengenai komunikasi, selanjutnya yang akan didefinisikan yaitu organisasi. Secara sederhana seperti yang telah kita semua ketahui, organisasi atau yang biasa disebut dengan lembaga, institusi, badan, atau sebutan lainnya merupakan kumpulan individuindividu yang berada dalam satu tempat yang memiliki tujuan bersama. Ada banyak definisi terkait organisasi, Arni Muhammad merumuskan 3 hal utama definisi organisasi dari beberapa tokoh, yaitu organisasi merupakan suatu sistem, organisasi mengkoordinasi aktivitas dan organisasi mencapai tujuan bersama (Muhammad, 2015, h. 24). Lagi-lagi tujuan bersama selalu disebut dalam definisi organisasi. Hal ini menggambarkan bahwa tujuan bersama menjadi hal penting, menjadi hal yang selalu ada di setiap organisasi apapun jenisnya. Jenis-jenis organisasi sangat beragam, ada yang sangat sederhana, ada juga yang sangat kompleks. Apapun jenis suatu organisasi, Scott menyampaikan bahwa dalam suatu organisasi terdapat lima elemen yaitu struktur sosial (pola hubungan antar anggota organisasi), partisipan (individu dalam organisasi), tujuan, teknologi (alat untuk menunjang kegiatan dalam organisasi), dan lingkungan (Muhammad, 2015, h. 25).

Di atas telah disampaikan definisi dari komunikasi dan organisasi. Secara garis besar, sudah dapat terlihat gambaran mengenai apa yang dimaksud dengan komunikasi organisasi. Sederhananya komunikasi organisasi adalah proses komunikasi (penyampaian informasi dari suatu individu atau kelompok ke individu atau kelompok lain) yang terjadi dalam suatu organisasi untuk mencapai tujuan bersama. Tujuan bersama, seperti yang telah dibahas dalam definisi organisasi, juga menjadi poin utama dalam komunikasi organisasi karena tujuan akhir dari segala aktivitas komunikasi yang dijalankan dalam organisasi adalah pencapaian tujuan bersama. Komunikasi organisasi lebih menekankan pada kegiatan penanganan pesan yang terdapat dalam batasan-batasan yang ada dalam organisasi (Pace, 2006, hal. 33). Penanganan pesan yang dimaksud adalah yang berhubungan dengan bagaimana pembuatan pesan tersebut, bagaimana pesan tersebut disampaikan, melalui media apa pesan tersebut disampaikan, bagaimana pesan tersebut sampai, dan lainnya.

Untuk mencapai tujuan bersama dari suatu organisasi, komunikasi organisasi menjadi kebutuhan 
Jurnal Edumaspul, 5 (2), Year 2021 - 417

(Lydia Fahmawati, Cheerli, Idham Imarshan)

individu sebagai media ataupun sistem yang menunjang, mendukung dan juga membatasi kegiatankegiatan dalam organisasi. Dalam praktiknya komunikasi organisasi memiliki empat fungsi (Senjadja, 1994, h. 136) yaitu, Pertama: Regulatif. Komunikasi organisasi dipandang sebagai suatu media atau sistem yang memberlakukan peraturan-peraturan dalam organisasi kepada anggotanya. Fungsi regulatif komunikasi organisasi ini akan berpengaruh terkait dengan dua hal, yang pertama seseorang berwenang, biasanya seorang pimpinan organisasi yang akan memberikan instruksi terkait dengan peraturan yang berlaku. Seseorang yang berwenang ini akan memberikan instruksi kepada anggota organisasi dalam melakukan kegiatan-kegiatan guna mencapai tujuan bersama. Hal kedua terkait dengan pesan atau informasi yang mencakup peraturan tentang pekerjaan yang dibutuhkan oleh anggota organisasi. Peraturan yang disampaikan kepada anggota organisasi ini mencakup informasi yang jelas terkait dengan batasan pekerjaan, apa saja yang boleh atau tidak boleh dilakukan dalam menjalankan pekerjaan. Kedua: Informatif. Komunikasi organisasi dipandang sebagai suatu media atau sistem pemrosesan informasi, di mana setiap anggotanya mendapatkan informasi yang tepat dan uptodate sesuai dengan kebutuhan untuk menunjang pekerjaan. Informasi ini dibutuhkan oleh anggota organisasi untuk memberikan gambaran mengenai kegiatan yang akan dilakukan untuk mencapai tujuan bersama. Tentunya, terdapat perbedaan-perbedaan jenis informasi yang akan disampaikan kepada anggota organisasi bergantung pada fungsi dan jabatannya di struktur organisasi. Jenis informasi yang dimaksud adalah ada informasi yang bisa disampaikan kepada semua anggota dan ada informasi yang hanya berada pada tingkat atau level jabatan tertentu. Ketiga: Integratif. Komunikasi organisasi dipandang sebagai suatu media atau sistem yang menyediakan saluran komunikasi yang memungkinkan anggota organisasi dapat menjalankan tugas dan kewajibannya dengan baik. Saluran komunikasi yang dimaksud dapat dalam bentuk formal maupun informal. Keempat: Persuasif. Komunikasi organisasi dipandang sebagai suatu media atau sistem yang membuat anggotanya melakukan kegiatankegiatan sesuai dengan peraturan organisasi untuk mencapai tujuan bersama. Cara-cara yang dilakukan untuk membuat anggota melakukan tugasnya dengan baik tentunya berbeda-beda, sesuai dengan gaya kepemimpinan dan budaya organisasi masing-masing. Namun bisa dipastikan cara-cara yang digunakan tersebut bertujuan untuk mengajak anggota organisasi untuk mau melakukan tugasnya dengan sukarela berlandaskan tanggung jawab bukan karena paksaan.

\section{Metode (15\%)}

Jenis penelitian ini adalah penelitian deskriptif dengan pendekatan kualitatif yang mana peneliti menggunakan latar alamiah untuk berusaha memahami fenomena yang terjadi, dalam konteks ini fenomena tersebut adalah komunikasi organisasi internal di Kalbis Institute selama masa Pandemi COVID-19 pada bulan Februari 2020-Januari 2021. Metode penelitian yang digunakan dalam penelitian ini adalah studi kasus. Studi kasus merupakan salah satu metode penelitian sosial yang sesuai dengan namanya, meneliti kasus untuk mempelajari latar belakang, keadaan, dan interaksi yang terjadi. Peneliti menggunakan metode studi kasus dalam penelitian ini karena menurut Yin, metode studi kasus cocok untuk penelitian yang fokus penelitiannya terletak pada fenomena masa kini dalam konteks kehidupan nyata dan menguraikan hal-hal unik dari fenomena komunikasi yang diteliti (2013, hal. 18).

Objek dalam penelitian ini adalah komunikasi organisasi Kalbis Institute selama masa Pandemi COVID-19. Sedangkan subjek dalam penelitian ini adalah karyawan Kalbis Institute. Dalam penelitian kualitatif, sampel harus mewakili ciri-ciri suatu populasi dalam kasus yang diteliti (Moleong, 2002, hal. 224). Untuk menentukan informan, peneliti menggunakan teknik purposive. Dengan teknik ini informan ditentukan berdasarkan tujuan dan maksud tertentu yang harus mencerminkan populasi. Informan dalam penelitian ini ditentukan berdasarkan kebutuhan akan pelaksanaan komunikasi organisasi yang berlangsung di Kalbis Institute. Jika dilihat dari empat fungsi komunikasi yang ada, informan dalam penelitian ini terdiri dari Human Capital Kalbis Institute sebagai unit pelaksana komunikasi organisasi dan karyawan Kalbis Institute sebagai khalayak yang berpartisipasi dalam komunikasi organisasi. Untuk mempermudah peneliti dalam mengumpulkan data informan karyawan Kalbis Institute dibagi berdasarkan tingkat dan jenis jabatan yaitu, rektorat (rektor, wakil rektor dan dekan), kepala unit (ketua program studi dan manager) dan staf. Teknik pengumpulan data yang digunakan dalam penelitian ini adalah wawancara dan pengecekan dokumentasi. Wawancara kepada informan dan pengecekan dokumentasi yang dimaksud adalah media komunikasi organisasi yang digunakan selama masa Pandemi COVID-19 berlangsung.

\section{Hasil dan Pembahasan}

Pandemi COVID-19 di Indonesia telah berlangsung sejak awal mula masuknya COVID-19 ke Indonesia yaitu pada bulan Maret 2020 dan sampai dengan penelitian ini selesai dilakukan sampai dengan bulan Januari 2021, belum juga berakhir karena jumlah kasus positif yang masih terus bertambah. Pada Selasa, 
5 Januari 2021, di situs website Komite Penanganan COVID-19 dan Pemulihan Ekonomi Nasional tercatat kasus positif sebanyak 772.103, angka kesembuhan sebanyak 639.103 dan angka kematian sebanyak 22.911. Situasi dan kondisi tersebut berdampak pada banyak hal, salah satunya pada komunikasi di dalam suatu organisasi.

Kalbis Institute merupakan salah satu perguruan tinggi terbaik di Jakarta. Sebagai sebuah organisasi, Kalbis Institute memiliki kurang lebih 140 karyawan yang terdiri dari dosen dan tenaga kependidikan. Dalam pelaksanaan komunikasi organisasi di Kalbis Institute tidak ada departemen khusus yang bertangungg jawab akan fungsi ini. Secara praktiknya fungsi komunikasi organisasi dilaksanakan oleh Departemen Human Capital dan juga para pimpinan. Seperti yang telah disampaikan di atas, Pandemi COVID-19 berdampak pada komunikasi organisasi. Begitu pula dengan Kalbis Institute, Pandemi COVID19 berdampak pada perubahan bentuk fungsi komunikasi organisasi. Untuk dapat menjelaskan fungsi komunikasi organisasi di Kalbis Institute pada masa Pandemi COVID-19, berikut di bawah ini merupakan uraiannya.

\section{Fungsi Regulatif}

Fungsi regulatif komunikasi organisasi berkaitan dengan peraturan-peraturan yang berlaku di suatu organisasi. Peraturan-peraturan yang berlaku tersebut tentunya diterapkan dengan tujuan untuk dapat mencapai tujuan organisasi. Dengan adanya Pandemi COVID-19, Pemerintah Indonesia mengeluarkan beberapa peraturan, keputusan, surat edaran dan lainnya terkait dengan upaya pencegahan dan penekanan penularan COVID-19. Berdasarkan website Komite Penanganan COVID-19 dan Pemulihan Ekonomi Nasional, tercatat sampai dengan awal bulan Januari 2021, terdapat sekitar sembilan puluh peraturan ataupun kebijakan yang dikeluarkan oleh Pemerintah Indonesia. Dengan jumlahnya yang sama juga terdapat protokol-protokol kesehatan yang dianjurkan oleh Pemerintah. Peraturan, kebijakan dan protokol kesehatan yang dikeluarkan oleh Pemerintah tersebut tentunya harus diikuti oleh Kalbis Institute. Secara garis besar, sebagai perusahaan yang mematuhi peraturan dan taat hukum, Kalbis Institute selalu menerapkan peraturan, kebijakan dan protokol kesehatan yang dikeluarkan oleh Pemerintah. Hal tersebut disampaikan oleh informan, "Kalbis Institute termasuk perusahaan yang taat dengan aturan".

Sejak masuknya COVID-19 ke Indonesia pada awal bulan Maret 2020 yang informasinya didapatkan dari pemberitaan di televisi dan juga sosial media. Pemerintah Indonesia melakukan pengawasan ketat jalur masuk ke Indonesia dan menutup sementara penerbangan ke China. Dalam upaya merespon dan mencegah penularan COVID-19 pada tanggal 3 Maret 2020 Kalbis Institute melalui Departemen Human Capital mengeluarkan Internal Memo terkait dengan kepulangan karyawan dari perjalanan luar negeri dan karyawan yang sakit. Memo Internal tersebut berisikan himbauan kepada karyawan yang baru pulang dari perjalanan luar negeri untuk memakai masker selama di kantor selama dua minggu dan apabila ada karyawan yang sakit direkomendasikan untuk menggunakan masker selama di kantor, kemudian segera memeriksakan diri ke rumah sakit dan apabila bila dinyatakan sakit agar tidak ke kantor hingga benarbenar sudah sembuh. Kemudian melengkapi Internal Memo tersebut, pada tanggal 6 Maret 2020 Kalbis Institute kembali mengeluarkan Internal Memo melalui Departemen Human Capital terkait dengan Aturan Kewaspadaan Pencegahan COVID-19. Internal Memo tersebut berisikan tentang himbauan kepada karyawan untuk tidak melakukan perjalanan ke luar negeri, apabila perjalanan harus dilakukan maka harus melakukan isolasi mandiri selama 14 hari dan melaporkan data kesehatan diri. Kemudian karyawan juga dihimbau untuk menghindari kontak dengan orang yang sakit, melakukan pencegahan mandiri dengan selalu memakai masker, rajin mencuci tangan, menjaga kesehatan dengan rajin berolah raga, mengkonsumsi makanan yang sehat, dan melaporkan tamu asing yang datang ke Kalbis Institute.

Selain itu, dalam merespon dan pencegahan penularan serta penyebaran COVID-19, Kalbis Institute mulai mengubah beberapa kegiatan yang awalnya tatap muka langsung atau luring menjadi daring. Dikarenakan Kalbis Institute merupakan institusi perguruan tinggi, maka kegiatan utamanya adalah belajar dan mengajar. Sesuai dengan instruksi dari Pemerintah Indonesia melalui Presiden Joko Widodo untuk seluruh masyarakat Indonesia melalukan semua kegiatan termasuk belajar, bekerja dan beribadah dari rumah. Berdasarkan himbauan tersebut Kalbis Institute memberlakukan pembelajaran jarak jauh mulai tanggal 18 Maret 2020 melalui Surat Edaran No. 001/REKTOR-SE/III/2020 mengenai Langkah dan Upaya Pencegahan COVID-19 di Lingkungan Kalbis Institute. Isi dari surat edaran tersebut adalah pengalihan kegiatan perkuliahan, kelas praktik dan bimbingan tugas akhir dialihkan menjadi online learning sampai dengan 13 April 2020. Contoh kegiatan lainnya yang harus beralih menjadi online adalah pertemuan mingguan pimpinan Kalbis Institute yang disebut dengan Homebase Meeting yang terdiri dari Rektor, Wakil Rektor, Dekan, Ketua Program Studi, Sekretaris Program Studi, dan Manager Departemen. Sejak 6 Maret 2020 pertemuan mingguan pimpinan Kalbis Institute tersebut sudah beralih 
menjadi pertemuan online melalui Zoom Meeting. Kegiatan-kegiatan lainnya seperti Pameran Kerja atau yang biasa disebut dengan Kalbis Career Day yang biasanya setiap tahun dilakukan secara langsung di Lobby Kalbis Institute menghadirkan ratusan orang untuk hadir, dikarenakan COVID-19, maka pelaksanaannya dilakukan secara online atau virtual berbasis website. Tidak hanya itu, kegiatan-kegiatan kampus seperti orientasi penerimaan mahasiswa baru atau yang biasa disebut dengan Kalbispheration pun diadakan secara virtual. Semua kegiatan-kegiatan mahasiswa pun harus dialihkan menjadi online seperti kegiatan kompetisi, kegiatan minat bakat, dan lainnya. Segala aktivitas yang ada di Kalbis Institute selama Pandemi COVID-19 ini harus dengan persetujuan dari Tim Gugus Tugas Pencegahan COVID-19 Kalbis Institute.

Kemudian pada tanggal 17 Maret 2020 melalui Departemen Human Capital, Kalbis Insitute mengeluarkan Internal Memo No. 007/HR-IM/III/2020 tentang Kebijakan Bekerja di Rumah (Work From Home) Sebagai Langkah dan Upaya Pencegahan COVID-19 di Lingkungan Kalbis Institute. Internal Memo tersebut berisikan ketentuan bekerja dari rumah dari tanggal 18 Maret 2020 sampai dengan tanggal 31 Maret 2020 dengan melaporkan hasil pekerjaan kepada atasan masing-masing, memastikan komunikasi dan koordinasi kerja berjalan baik dengan selalu dapat dihubungi apabila dibutuhkan, karyawan dihimbau untuk tetap di rumah dan membatasi interaksi sosial serta menjaga kesehatan dan kebersihan. Untuk tetap menjaga siklus pekerjaan berjalan dengan baik, karena ada beberapa pekerjaan yang tidak bisa dikerjakan dari rumah maka Departemen Human Capital menyediakan jadwal masuk karyawan bergantian selama sistem Work From Home diberlakukan.

Dikarenakan Pandemi COVID-19 tidak kunjung reda malah semakin terus bertambah, Kalbis Institute kembali memperpanjang pemberlakuan sistem Work From Home dengan kebijakan full Work From Home artinya tidak ada jadwal masuk bergantian, hanya unitunit seperti Building Managament saja yang masih harus ke kantor. Pemberlakukan sistem full Work From Home ini berlangsung selama kurang lebih dua bulan, sejak tanggal 1 April sampai dengan 29 Mei 2020. Untuk dapat menjaga kinerja karyawan, karyawan diwajibkan untuk melakukan presensi checkin dan checkout di website Human Resource Information System di laman hrd.kalbis.ac.id. dalam Internal Memo ini karyawan juga diingatkan kembali untuk dapat bekerja semaksimal mungkin di tengah situasi yang ada, menjalankan kewajiban dan melaporkan setiap pekerjaan, melakukan diskusi dan pertemuan secara online untuk menunjang pekerjaan, dan menjaga kesehatan.
Dengan semakin meningkatnya kasus COVID19, Kalbis Institute melalui Departemen Human Capital kembali mengeluarkan Internal Memo pada tanggal 7 April 2020 tentang pemakaian masker dan tidak menggunakan kendaraan umum. Kemudian untuk menjaga kelancaran dan keseragaman pelaporan kerja, karyawan diwajibkan untuk mengisi fitur Daily Activity di website HRIS Kalbis Institute pada 15 April 2020. Kemudian pada 11 Mei 2020, bersamaan dengan momen Hari Raya Idul Fitri $1441 \mathrm{H}$ dan menyesuaikan Surat Keputusan Bersama beberapa menteri terkait dengan Perubahan Cuti Bersama Hari Raya Idul Fitri $1441 \mathrm{H}$, Kalbis Institute pun mengeluarkan Internal Memo untuk juga menerapkan cuti sesuai arahan dari beberapa menteri tersebut. Selain itu akibat dari Pandemi COVID-19 yang berdampak kepada seluruh lini usaha termasuk Kalbis Institute, dalam pemberian Tunjangan Hari Raya terdapat beberapa perubahan sejalan dengan Surat Edaran Menaker No. M/6/HI.00.01/V/2020 tentang Pemberian Tunjangan Hari Raya pada tahun 2020 di masa Pandemi COVID19.

Kalbis Institute mengikuti peraturan dari Pemerintah Provinsi DKI Jakarta dalam menerapkan sistem Work From Home. Pembatasan Sosial Berskala Besar (PSBB) yang ditetapkan oleh Pemerintah Provinsi DKI Jakarta telah diperpanjang sebanyak tiga kali dan yang terakhir pada 22 Mei sampai 4 Juni 2020. Menyesuaikan peraturan tersebut, Kalbis Institute pun mulai menerapkan kembali bekerja ke kantor dengan jadwal kerja bergantian sampai dengan tanggal 30 Juni 2020 melalui Internal Memo No. 017/HR-IM/V/2020 tentang Ketentuan dan Konsep Tahapan Back to Work From Office dalam Situasi Wabah COVID-19 yang dikeluarkan pada tanggal 31 Mei 2020. Kalbis Institute juga menerapkan peraturan Pemerintah terkait dengan kapasitas maksimal karyawan yang boleh datang ke kantor.

Fungsi regulatif komunikasi organisasi internal yang dilakukan Kalbis Institute pada dasarnya telah berjalan dengan baik, terlihat dari peraturan-peraturan yang ditetapkan telah uptodate dengan menyesuaikan peraturan dari Pemerintah dan pihak-pihak terkait. Selain itu peraturan yang diterapkan tersebut juga telah memperhatikan kesejahteraan karyawan agar tetap dapat menjalankan pekerjaannya dengan baik. Dalam menghadapi Pandemi COVID-19 ini juga Kalbis Institute telah menerapkan beberapa hal baru untuk tetap dapat menjaga kinerja karyawan berjalan dengan baik agar tujuan organisasi dapat tercapai meski di tengah situasi dan kondisi krisis. Inovasi yang dilakukan yaitu dengan menerapkan kewajiban melakukan presensi secara online dengan melakukan checkin dan checkout yang sebelum adanya Pandemi COVID-19, presensi dilakukan dengan memindai sidik 
Jurnal Edumaspul, 5 (2), Year 2021- 420

(Lydia Fahmawati, Cheerli, Idham Imarshan)

jari menggunakan alat yang ada di Lobby Kalbis Institute. Pada awal tahun 2021 ini, peraturan presensi ditambah lagi dengan harus mencantumkan foto selfie menggunakan aplikasi GPS Camera. Hal tersebut untuk mengetahui lokasi karyawan saat menjalani Work From Home. Kemudian untuk memastikan karyawan menjalankan tugas pekerjaannya dengan baik, setiap karyawan diwajibkan melaporkan pekerjaannya melalui fitur Daily Activity di situs website Human Resources Information System (HRIS) Kalbis Institute. Selain itu, untuk mendukung terciptanya komunikasi dan koordinasi pekerjaan berjalan dengan baik, maka setiap unit diwajibkan untuk melakukan Morning Briefing setiap harinya melalui virtual meeting yang harus dicantumkan ke dalam Daily Activity di HRIS.

Meskipun fungsi regulatif komunikasi organisasi internal telah dijalankan dengan baik oleh Kalbis Institute, namun terdapat beberapa masukan dari karyawan terkait dengan peraturan-peraturan yang diterapkan tersebut. Masukan tersebut di antaranya adalah terkait dengan jarak waktu sosialisasi peraturan dengan penerapan peraturannya agar tidak terlalu dekat. Hal ini untuk memberikan waktu kepada karyawan untuk dapat mempelajari peraturan yang akan diterapkan tersebut. Namun, mengingat peraturan yang harus segera diterapkan dan keluangan waktu yang sempit menjadi kendala yang akhirnya mengharuskan Kalbis Institute menempatkan sosialisasi dan penerapan dalam waktu yang dekat.

\section{Fungsi Informatif}

Sebagai fungsi informatif, komunikasi organisasi dipandang sebagai suatu media atau sistem pemrosesan informasi, di mana setiap anggotanya mendapatkan informasi yang tepat dan uptodate sesuai dengan kebutuhan untuk menunjang pekerjaan. Kalbis Institute telah menjalankan fungsi informatif komunikasi organisasi internal dengan baik. Hal tersebut disampaikan oleh para informan yang merupakan karyawan dari Kalbis Institute. Berdasarkan hasil wawancara dengan para informan, didapatkan informasi terkait dengan fungsi informatif komunikasi organisasi internal Kalbis Institute.

Selama masa Pandemi COVID-19 berlangsung yang kurang lebih hampir satu tahun lamanya, kita semua dituntut untuk bisa beradaptasi dengan keadaan di mana semua harus dilakukan secara online. Seperti yang telah dijabarkan di bagian Fungsi Regulatif Komunikasi Organisasi Kalbis Institute, Kalbis Institute telah menerapkan peraturan-peraturan Pemerintah. Peraturan-peraturan yang akan diterapkan oleh Kalbis Institute dikomunikasikan melalui e-mail yang dikirimkan oleh Manager Departemen Human Capital. Pengiriman e-mail dilakukan dalam jam kerja yaitu antara pukul delapan pagi sampai dengan pukul lima sore. Setelah mengirimkan e-mail terkait dengan peraturan yang akan diterapkan, Manager Departemen Human Capital kembali menginformasikan kepada seluruh karyawan Kalbis Institute melalui WhatsApp Group bahwa ada e-mail dari Departemen Human Capital terkait dengan peraturan yang akan diterapkan. Selain melalui e-mail dan WhatsApp Group, dalam mensosialisasikan peraturan yang akan diterapkan para pimpinan Kalbis Institute biasanya juga menyampaikannya melalui pertemuan mingguan pimpinan yang disebut dengan Homebase Meeting. Kemudian setelah itu informasi yang sampai kepada para pimpinan akan diteruskan kembali kepada timnya di departemen masing-masing.

Pelaksanaan fungsi informatif komunikasi organisasi internal Kalbis Institute hampir sama dengan beberapa organisasi lain yaitu menggunakan media e-mail dan juga WhatsApp. Informan memberikan masukan untuk juga dapat menggunakan website HRIS dalam mengkomunikasikan peraturanperaturan yang akan diterapkan sehingga memudahkan karyawan untuk bisa melihat update dan juga riwayat peraturan-peraturan yang ada.

\section{Fungsi Integratif}

Setiap organisasi harus dapat menyediakan saluran komunikasi yang memungkinkan karyawan untuk dapat menjalankan pekerjaannya. Kewajiban organisasi tersebut berhubungan dengan fungsi integratif komunikasi organisasi. Di masa Pandemi COVID-19 ini setiap organisasi diharuskan beradaptasi dengan situasi dan kondisi yang tidak memungkinkan untuk berkomunikasi tatap muka secara langsung. Kalbis Institute telah berupaya beradaptasi menghadapi situasi dan kondisi Pandemi COVID-19 dengan mengubah dan menambah saluran komunikasi untuk menunjang pekerjaan karyawan. Menurut Sanjaya, ada dua tipe saluran komunikasi yaitu saluran komunikasi formal dan informal (Sanjaya, 2007). Saluran komunikasi formal misalnya melalui e-mail, newsletter, bulletin, dan lainnya. Sedangkan saluran komunikasi informal misalnya melalui perbincangan pribadi antar karyawan, komunikasi ketika waktu istirahat atau makan siang bersama, dan lainnya.

Sebelum adanya Pandemi COVID-19, Kalbis Institute telah menyediakan saluran komunikasi yang memadai untuk menunjang pekerjaan karyawan. Saluran komunikasi formal yang disediakan yaitu di antaranya e-mail, rapat mingguan pimpinan, rapat mingguan unit, HRIS, dan WhatsApp Group. Saluran komunikasi informal yang disediakan yaitu adanya pertemuan seluruh karyawan pada momen tertentu seperti buka puasa bersama, halal bihalal setelah Hari Raya Idul Fitri, rekreasi karyawan, adanya waktu 
istirahat, menyediakan ruang kerja yang nyaman, menyediakan tempat ibadahan yang nyaman, menyediakan kantin yang memadai dan nyaman, dan lainnya. Saluran-saluran komunikasi tersebut disediakan untuk menjaga kelancaran komunikasi antar karyawan dan kenyamanan karyawan selama di Kalbis Institute.

Setelah adanya Pandemi COVID-19, pada dasarnya tidak banyak perubahan yang terjadi pada penyediaan saluran komunikasi di Kalbis Institute. Namun terdapat satu perubahan yang dilakukan yaitu, mengubah bentuk komunikasi yang tadinya tatap muka secara langsung menjadi komunikasi virtual atau online. Rapat mingguan pimpinan dan rapat mingguan unit yang biasa dilakukan dengan tatap muka secara langsung harus diubah menjadi rapat online di Zoom Meeting ataupun Google Meet. Kemudian untuk menambah kelancaran komunikasi dan koordinasi pekerjaan, Departemen Human Capital mewajibkan setiap unit untuk melakukan Morning Briefing setiap harinya dan diunggah ke dalam HRIS. Penggunaan $e-$ mail menjadi sangat penting dalam berkomunikasi secara resmi di masa Pandemi COVID-19 ini. Segala bentuk informasi terkait dengan pekerjaan disampaikan melalui e-mail oleh setiap departemen ke departemen lain atau ke pihak di luar Kalbis Institute. Informasi atau komunikasi yang disampaikan melalui e-mail di antaranya internal memo terkait dengan peraturan COVID-19 di lingkungan Kalbis Institute, internal memo terkait dengan pelaksanaan pengajuan dana, informasi terkait kegiatan yang akan diadakan oleh departemen tertentu, permintaan data kepada departemen tertentu, pengajuan dana kepada Departemen Finance, dan lainnya.

Pada awal Pandemi COVID-19, untuk berkomunikasi terkait dengan laporan pekerjaan kepada atasan, Kalbis Institute melalui Departemen Human Capital, membuatkan suatu template laporan harian yang harus diberikan staf kepada atasannya. Kemudian Kalbis Institute menyediakan saluran komunikasi laporan harian dengan menambahkan fitur Daily Activity di HRIS. Sehingga memudahkan setiap karyawan untuk mencatat pekerjaannya yang dilakukan sehari-hari. Meskipun terbilang jadi menambah pekerjaan baru bagi karyawan karena harus memasukan daftar pekerjaan ke HRIS, tapi manfaat yang dirasakan lebih besar dari effort atau usaha yang dilakukan. Karyawan jadi memiliki catatan administrasi pekerjaan yang dilakukan setiap hari dan hal tersebut dapat dijadikan penilaian tambahan bagi kinerja karyawan selain KPI.

\section{Fungsi Persuasif}

Dalam menghadapi situasi dan kondisi krisis seperti Pandemi COVID-19 ini, dibutuhkan motivasi untuk dapat tetap semangat dalam menjalankan tugas pekerjaan. Terlebih lagi kita harus beradaptasi dengan bekerja dan melakukan segala aktivitas dari rumah. Perasaan bosan, tidak nyaman, komunikasi yang berjalan tidak lancar, serta kendala-kendala lainnya tentu akan membuat karyawan demotivasi. Apalagi dalam menjalani sistem Work From Home sangat dibutuhkan kedewasaan dan tanggung jawab yang besar dari masing-masing pribadi karyawan untuk tetap dengan jujur menjalankan pekerjaan. Seperti yang kita ketahui bersama berkerja dengan sistem Work From Home, baik atasan maupun Departemen Human Capital tidak dapat langsung mengawasi. Upaya-upaya untuk menjaga dan meningkatkan motivasi kerja karyawan tersebut sangat penting untuk dilakukan agar pekerjaan dapat berjalan dengan lancar dan tujuan organisasi tetap dapat tercapai. Hal-hal yang berhubungan dengan upaya-upaya yang menjadikan karyawan menjalankan pekerjaannya dengan sukarela dan semangat merupakan salah satu fungsi persuasif komunikasi organisasi.

Di Kalbis Institute, pelaksanaan fungsi persuasif komunikasi organisasi telah dilakukan melalui pimpinan. Seperti yang telah dibahas dalam bagian Fungsi Integratif Komunikasi Organisasi di atas, untuk memperlancar koordinasi dalam pekerjaan, dibuat pertemuan-pertemuan di beberapa tingkat jabatan. Dalam pertemuan-pertemuan tersebut, selain membahas permasalahan-permasalahan yang ada, disampaikan juga terkait dengan peraturan yang akan diterapkan, kemudian di akhir ataupun di awal pertemuan biasanya pimpinan menyampaikan motivasi untuk setiap anggota tetap semangat dalam menyelesaikan permasalahan yang ada. Speech atau pidato yang biasanya disampaikan oleh pimpinan Kalbis Institute yaitu dalam hal ini Rektor, dipandang sebagai salah satu penyemangat bagi para anggotanya. Ditambah lagi dengan cara penyampaian oleh Rektor begitu sangat masuk ke dalam logika karena biasanya Rektor memberikan analogi-analogi kepada suatu kasus yang ada. Rektor dalam memberikan motivasi juga sering menggunakan quotes-quotes yang menarik.

Tindakan persuasif lainnya yang menambah karyawan untuk tetap semangat bekerja di tengah masa Pandemi COVID-19 ini adalah Kalbis Institute tetap memberikan gaji sebagaimana mestinya kepada karyawan. Mengingat di tengah masa Pandemi COVID-19 ini cukup banyak perusahaan yang harus berjuang dengan cara mengurangi jumlah karyawan dan atau memotong sementara gaji karyawan. Meskipun ketika memberikan Tunjangan Hari Raya, Kalbis Institute melakukannya secara bertahap dua kali yaitu ketika Hari Raya Idul Fitri dan Hari Raya Natal. Namun, dengan komunikasi yang disampaikan oleh Rektor kepada anggota pertemuan Homebase Meeting 
terkait dengan keadaan Kalbis Institute, maka para anggota dapat menerima dan memahami situasi dan kondisi yang ada. Informasi yang disampaikan oleh Rektor tersebut disampaikan oleh pimpinan masingmasing unit kepada para staf agar pemahaman dan penerimaan terkait dengan situasi dan kondisi yang ada juga didapatkan.

Namun tindakan persuasif tersebut belum terasa cukup dirasakan oleh karyawan. Perasaan aman dan nyaman juga sangat dibutuhkan untuk memotivasi karyawan dalam pekerjaan. Kepastian mengenai amannya karyawan dari penularan COVID-19 ketika bekerja di kantor menjadi hal yang penting di tengah masa Pandemi COVID-19 ini. Di Kalbis Institute sendiri, penerapan protokol kesehatan telah dijalankan sejak bulan Maret 2020. Melalui Tim Gugus Tugas Kalbis Institute, standar protokol kesehatan telah diterapkan yaitu kapasitas jumlah karyawan yang masuk ke dalam gedung dibatasi sesuai peraturan dari Pemerintah Provinsi DKI Jakarta, hanya membuka satu akses pintu masuk dan keluar agar dapat mengecek suhu tubuh setiap orang yang masuk untuk memastikan kesehatannya, menyediakan handsanitizer di setiap lantai, menyemprot seluruh ruangan secara berkala dengan cairan disinfektan, dan membatasi jumlah orang di dalam lift. Dengan menerapkan protokol kesehatan tersebut, Kalbis Institute menjaga keselamatan karyawan dari COVID-19.

Penularan COVID-19 di Indonesia jumlahnya terus meningkat setiap harinya. Jumlah tertinggi penambahan harian kasus positif COVID-19 terjadi pada Kamis, 7 Januari 2021 yaitu dengan jumlah 9.321 kasus. Dengan terus bertambahnya kasus positif COVID-19, ternyata penyebaran COVID-19 semakin mendekat. Di Kalbis Institute terdapat beberapa kasus seperti karyawan yang dinyatakan positif maupun karyawan yang kontak langsung dengan korban positif. Penanganan kasus COVID-19 yang cepat dan transparan di Kalbis Institute menjadi salah satu permintaan karyawan untuk menjaga keamanan dan keselamatan kerja. Dalam penanganan kasus COVID19 yang terjadi di karyawan atau pun keluarga karyawan Kalbis Institute, Kalbis Institute melalui Tim Gugus Tugas telah menanganinya dengan cepat. Penanganan dilakukan dengan menelusuri orang-orang yang memiliki kontak langsung dengan karyawan positif, memberikan fasilitas kepada karyawan untuk melakukan tes COVID-19, dan memberikan waktu kepada karyawan untuk isolasi mandiri di rumah.

Sampai dengan akhir tahun 2020, ternyata Pandemi COVID-19 tidak kunjung reda, malah sebaliknya angka kasus positif terus meningkat dan bertambah banyak. Pandemi COVID-19 ini tentunya mengubah kebiasan-kebiasaan yang ada. Pada tahun-tahun sebelumnya, pada penghujung akhir tahun, biasanya di
Kalbis Institute selalu mengadakan pertemuan untuk menjadikan momen kebersamaan. Pandemi COVID-19 ini juga membuat hubungan antar karyawan menjadi renggang karena biasanya dapat tatap muka langsung ketika makan siang atau rapat suatu acara atau bahkan bertemu di depan toilet, setelah adanya COVID-19 jika jadwal Work From Office-nya tidak sama, maka hampir satu tahun tidak pernah bertemu. Dikarenakan hal tersebut, karyawan memberikan masukan untuk tetap diadakan pertemuan dengan seluruh karyawan pada momen tertentu meskipun dalam bentuk online. Hal tersebut untuk terus menjaga hubungan baik sesama karyawan dan juga mengingatkan kembali bahwa meskipun dalam keadaan krisis, kebersamaan tetap harus terjaga. Pada momen bulan ramadhan, Kalbis Institute telah mengadakan buka puasa bersama secara online dengan seluruh karyawan Kalbis Institute. Kegiatan tersebut sangat mempererat komunikasi dan hubungan baik sesama karyawan. Alangkah lebih baiknya jika pertemuan momen lainnya juga diadakan pertemuan serupa, seperti halal bihalal, natal, farewell akhir tahun, dan kickoff tahun baru misalnya.

\section{Simpulan}

Seperti yang telah disampaikan dalam bagian Pembahasan, terdapat empat fungsi komunikasi organisasi yaitu fungsi regulatif, informatif, integratif, dan persuasif. Keempat fungsi komunikasi organisasi tersebut telah dijalan dengan baik oleh Kalbis Institute baik sebelum maupun pada saat masa Pandemi COVID-19. Jika dapat disimpulkan satu persatu, pada pelaksanaan fungsi regulatif komunikasi organisasi, Kalbis Institute telah dengan taat menyesuaikan peraturan-peraturan dari Pemerintah. Tentunya penerapan peraturan tersebut telah disesuaikan dengan kepentingan dan keselamatan seluruh karyawan. Pada pelaksanaan fungsi informatif komunikasi organisasi, Kalbis Institute telah menyampaikan peraturanperaturan yang akan diterapkan dengan cara mensosialisasikan terlebih dahulu kepada seluruh karyawan. Pada pelaksanaan fungsi integratif komunikasi organisasi, dalam menyampaikan informasi Kalbis Institute menggunakan saluransaluran komunikasi yang telah disepakati dan ketahui oleh seluruh karyawan baik saluran komunikasi formal maupun informal. Pada pelaksanaan fungsi persuasif komunikasi organisasi, di tengah situasi dan kondisi krisis seperti Pandemi COVID-19, pimpinan Kalbis Institute terus berupaya memotivasi seluruh karyawan untuk tetap semangat dalam menjalani tugas pekerjaan. Selain itu, untuk menjaga rasa aman dan nyaman, Kalbis Institute terus menerapkan protokol kesehatan sesuai dengan standar dan anjuran dari Pemerintah. 
Di samping bentuk-bentuk komunikasi organisasi yang sudah dengan baik dilaksanakan oleh Kalbis Institute seperti yang dijabarkan di atas, tentunya tetap diperlukan perbaikan-perbaikan untuk peningkatan kualitas komunikasi organisasi. Perbaikan-perbaikan yang harus dilakukan di antaranya adalah jarak waktu yang cukup minimal satu minggu antara sosialisasi dengan penerapan peraturan, pemanfaatan Human Resources Information System sebagai tambahan saluran komunikasi untuk sosialisasi peraturan-peraturan yang diterapkan, tetap mengadakan pertemuan-pertemuan pada momen tertentu secara virtual untuk menjaga komunikasi dan hubungan baik antar karyawan dan hubungan baik antara karyawan dengan Kalbis Institute tetap terjaga, transparansi informasi terkait dengan kasus positif COVID-19 di lingkungan Kalbis Institute agar karyawan segera dapat melakukan isolasi mandiri dan pengecekan COVID-19 apabila memang memiliki kontak langsung dengan karyawan positif. Penelitian selanjutnya mengenai fungsi komunikasi organisasi dapat terus dikembangkan, mengingat masa Pandemi COVID-19 ini belum juga berakhir sampai dengan penelitian ini rampung. Dengan terus berlanjutnya Pandemi COVID-19 ini tentunya organisasi akan terus memperbaiki diri dalam rangka beradaptasi dengan situasi dan kondisi yang ada untuk mendapatkan pola komunikasi organisasi yang terbaik. Pengembangan penelitian mengenai fungsi komunikasi organisasi di masa krisis juga dapat dilakukan di beberapa organisasi atau lokasi yang berbeda.

\section{Daftar Pustaka}

[1] Pane, Merry Dame Cristy. (2020, Desember 16). COVID-19. Diakses pada 17 Desember 2020 dari Alodokter: https://www.alodokter.com/covid-19

[2] Komite Penanganan COVID-19 dan Pemulihan Ekonomi Nasional. (2020). Regulasi. Diakses pada 4 Januari 2021 dari https://covid19.go.id/p/regulasi

[3] Ihsanudin. (2020, Desember 16). Jokowi: Kerja dari Rumah, Belajar dari Rumah, Ibadah di Rumah Perlu Digencarkan. Diakses pada 17 Desember 2020 dari Kompas.com: https://nasional.kompas.com/read/2020/03/16/154 54571/jokowi-kerja-dari-rumah-belajar-darirumah-ibadah-di-rumah-perludigencarkan?page $=$ all
[4] Prasetyo, Andhika. (2020, Maret 3). Pemerintah Jamin Ketersediaan Bahan Pokok. Diakses pada 17 Desember 2020 dari Media Indonesia: https://mediaindonesia.com/read/detail/293897pemerintah-jamin-ketersediaan-bahan-pokok.html

[5] Zuali, Syawaluddin., Jumaidin, La Ode., Sirajuddin. (2017). Fungsi Komunikasi Organisasi pada Peningkatan Disiplin Kerja Pegawai Badan Kepegawaian Daerah (BKD) Kota Kendari. Jurnal Ilmu Komunikasi Universitas Halu Oleo. Diakses dari: http://ojs.uho.ac.id/index.php/KOMUNIKA SI/article/view/2706

[6] Littlejohn, Stephew W., Foss, Karen A. (2019). Teori Komunikasi. Jakarta: Salemba Humanika.

[7] Muhammad, Arni. (2015). Komunikasi Organisasi. Jakarta: Bumi Aksara.

[8] Pace, R. Wayne., Faules, Don F. (2006). Komunikasi Organisasi: Strategi Meningkatkan Kinerja Perusahaan. Bandung: PT Remaja Rosdakarya.

[9] Senjadja, Sasa Djuarsa. (1994). Jakarta: Universitas Terbuka.

[10] Yin, Robert K. (2013). Studi Kasus: Desain dan Penelitian. Jakarta: RajaGrafindo.

[11] Moleong, Lexy J. (2012). Metodologi Penelitian Kualitatif: Edisi Revisi. Bandung: PT Remaja Rosdakarya.

[12] Mutiara, Yunisa, Abdullah, Muh. Zein, Saidin. (2017). Komunikasi Organisasi Internal pada Karyawan Kantor Perwakilan Bank Indonesia Provinsi Sulawesi Tenggara. Jurnal Ilmu Komunikasi Universitas Halu Oleo. Diakses dari:

http://ojs.uho.ac.id/index.php/KOMUNIKASI /article/view/2711

[13] Sanjaya, Wina. (2007). Strategi Komunikasi Efektif. Yogyakarta: Media Abadi.

\section{Profil Penulis}

Lydia Fahmawati, Cheerli dan Idham Imarshan merupakan mahasiswa Magister Ilmu Komunikasi Jurusan Korporat Komunikasi di Universitas Pramadina 